\title{
The Causes and Outcomes of Coup During Civil War*
}

\author{
CURTIS BeLL ${ }^{\dagger}$ \\ University of Tennessee \\ JUN KOGA SuDDUTH ${ }^{\ddagger}$ \\ University of Strathclyde
}

\begin{abstract}
Though approximately one in four coup attempts takes place during an ongoing civil war, scholars have not yet analyzed how the incidence of civil war affects coup attempts and outcomes. We conduct the first empirical analysis of the relationship between ongoing civil war and coup activity, finding (1) war increases the risk of coup attempt, though (2) war-time coup attempts are significantly less likely to be successful and (3) the risk of war-time coup is much higher when states face stronger rebel groups that pose greater threats to the political survival of the incumbent government. We attribute these findings to the pernicious effect of ongoing war on the welfare of the military elites and soldiers who have the greatest capacity to execute a coup attempt. As war diminishes their welfare and creates uncertainty about the future of the state, potential plotters become more willing to accept riskier coup attempts than they might plot during peace-time. Coup motivations are greatest when incumbents are more likely to lose their wars, and this causes coup plotters to attempt more and riskier coups when rebels are relatively strong.
\end{abstract}

*NOTE: The data and all computer code necessary to replicate the results and figures in this analysis will be made publicly available at the authors' homepages on publication. R and Stata 12 was used for all statistical analyses.

${ }^{\dagger}$ Assistant Professor of Political Science, University of Tennessee at Knoxville, 1001 McClung Tower University of Tennessee Knoxville, TN, USA 37919 (curtis.bell@tennessee.edu).

${ }^{\ddagger}$ Lecturer, University of Strathclyde, School of Government and Public Policy, McCance Building 16 Richmond Street, Glasgow G1 1QX, UK (jun.koga@strath.ac.uk). 
Coup d'état and civil war pose formidable threats to the political survival of the world's more vulnerable leaders and, importantly, these threats typically occur contemporaneously. Between 1990 and 2010, approximately half of the 71 states that suffered civil war also endured at least one coup attempt. ${ }^{1} 75 \%$ of the states that saw coup activity also experienced civil war. ${ }^{2} \mathrm{We}$ would expect conflict-prone states to be more susceptible to coup-the literatures on coup and civil war identify several common risk factors (poverty, recent conflict, etc.) — but does civil war also have an independent influence on the risk of coup activity? How might war change a coup plotter's calculus? Are war-time coup attempts any more or less likely to be successful than those attempted during peace-time?

Despite the prevalence of inseparably linked civil wars and coup attempts (consider recent examples in Mali, Peru, Sierra Leone, Ethiopia, and elsewhere), the academic literatures on coup and civil war have developed independently without much consideration of the other. ${ }^{3}$ Researchers have only recently begun to study links between coup and civil war (Roessler 2011, Thyne 2015) and we know of no previous work that rigorously examines how ongoing war might shape coup events and coup outcomes in a large cross-national sample. Efforts to unite these literatures can complement the growing body of work that examines political stability from the perspective of leaders looking to maximize their chances of survival while facing multiple types of threats (Bueno de Mesquita et al. 2003, Chiozza \& Goemans 2011).

We conduct the first quantitative analysis of the relationship between civil war and coup, finding (1) civil war increases the risk of coup attempt, though (2) war-time coup attempts are significantly less likely to be successful and (3) the risk of war-time coup is much higher when states face stronger rebel groups that pose greater threats to the political survival of the incumbent

\footnotetext{
${ }^{1}$ We follow the Uppsala Conflict Data Program (Themnér \& Wallensteen 2012) and define civil conflict using the 25 battle death threshold. We use the coup list assembled by Powell and Thyne (2011).

${ }^{2}$ These frequencies account for the possibility of exceptionally violent coups being coded as both coups and civil conflicts (see the data section below). Overall, ten states experienced coup but no war, 38 experienced war but no coup, and 33 suffered both war and coup.

${ }^{3}$ See thorough literature reviews by Blattman and Miguel (2010) and Sambanis (2004).
} 
government. We argue the correlations between civil war, coup attempts, and coup outcomes are neither coincidental nor spurious. Rather, ongoing war affects the strategic logic of coup by altering plotter expectations over the future of the state and diminishing plotter satisfactionpeace-time with the status quo. This finding, when coupled with recent work on the conflict-related consequences of coup-proofing (Pion-Berlin \& Trinkunas 2007, Quinlivan 1999, Roessler 2011), improves our understanding of the security trade-offs made by the leaders of insecure states.

\section{Disposition, Capacity, and Coup d'État}

The literature on coup d'état generally characterizes coup as an outcome of a careful decisionmaking process in which potential coup plotters juxtapose their satisfaction with the incumbent leader in the status quo against the perceived benefits and risks associated with a coup attempt. This rational choice approach studies coup from the perspective of potential coup instigators, who are typically members of the military or high-profile civilians with significant military support. ${ }^{4}$ The approach focuses attention on two broadly-defined drivers of coup activity: plotter capacity to initiate successful coups and plotter disposition in the status quo. When potential plotters have greater capacity, coup attempts are more likely to succeed and plotters can more confidently accept the risks and costs associated with an attempt to overthrow a government. Dissatisfaction with the status quo leaves potential plotters more favorably disposed toward coup activity because the consequences of inaction are less favorable. This framework for understanding coup behavior provides the foundation for much of the contemporary literature, both game theoretic (Acemoglu \& Robinson 2006, Gallego \& Pitchik 2004, Svolik 2009) and non-formal (Finer 1988, Powell 2012). ${ }^{5}$

\footnotetext{
${ }^{4}$ More than $80 \%$ of the coup attempts in the Thyne and Powell dataset were attempted by high-ranking officers, such as generals, colonels, admirals, commanders, defense ministers, and majors. Nearly $15 \%$ were organized by lower-ranking officers, NCOs, and soldiers.

${ }^{5}$ What we are calling plotter disposition has also been called plotter motivation, plotter satisfaction, and/or plotter opportunity cost elsewhere in the literature. All of these terms acknowledge the same common concept: coups become more likely when potential plotters believe they have less to lose in the status quo. Similarly, plotter capacity has also been called opportunity, ability, capability, or power. We use these terms interchangeably throughout the paper and define capacity as the likelihood with which which an attempted coup would succeed.
} 
Studies of plotter capacity highlight conditions that lead potential coup plotters to perceive coup attempts might be exceptionally likely to succeed. The likelihood of a successful coup varies greatly with each potential plotter's unique organization, military rank, and access to the incumbent leader - a cabinet-level general will almost always have greater capacity than a lowranking private, for example-but previous research links coup frequency to several sociopolitical conditions that generally improve plotter capacity. Greater military capabilities (Kposowa \& Jenkins 1993, Powell 2012) embolden military leaders, while promises of foreign support reaffirm beliefs that friendly governments will help plotters sustain their regimes and prevent counter-coups (Thyne 2010). Poor economic performance and widespread perceptions of regime illegitimacy can boost the public's willingness to condone a coup after the attempt, which is crucial to plotter capacity because tactically-successful coups can be overturned and reversed by widespread disapproval among the military or general public (Belkin \& Schofer 2003, Lindberg \& Clark 2008, Londregan \& Poole 1990, Luttwak 1969). Potential plotters are also more optimistic about their chances of success when their conspiracies target new leaders and when their own coup attempts might be legitimized by a history of coup in the country or an incumbent military government (Powell 2012, Belkin \& Schofer 2003).

Some scholars argue that because some subset of military elites typically possesses the access and influence needed to pose a viable coup threat, sufficient plotter capacity is omnipresent and the prevalence of coup attempts might be better explained by the disposition of these most capable potential plotters. Researchers approaching the coup problem from this perspective stress the disposition of military elites and emphasize the importance of the incumbent regime's efforts to satisfy their interests. Nordlinger (1977) argues, for example, that the inherent power of the military elite forces civilian leaders to tend to military corporate interests if they are to stay in power. Leaders may work to improve a potential plotter's satisfaction with the status quo with appeasement strategies such as special appointments to positions of authority, increased military spending and arms procurement, private rents to military elites, or greater military autonomy 
(Arriola 2009, Bell 2011, Quinlivan 1999, Powell 2012, Wang 1998). This was evident in Uruguay, where the transition to civilian democracy was made possible by agreements such as the Naval Club Pact (1985), which guaranteed military elites continued access, amnesty, and security in exchange for unambiguous support for upcoming democratic elections (Gillespie 1991). Here, the threat of coup was effectively reduced with targeted appeasement meant to improve the disposition of the most capable potential plotters.

Unfortunately for leaders, increasing the satisfaction of the military elites who constitute the greatest coup threat often entails strengthening the military and allowing it to pose a more viable coup threat in the future (Feaver 1999, Svolik 2009). Attempted coups are more likely to succeed when the military holds political power (Powell 2012, Svolik 2009), and some research finds higher levels of military spending similarly increase coup success rates (Wang 1998). When threatening potential plotters are brought into the leader's inner circle rather than marginalized, efforts to overthrow the government are more likely to result in success (Powell 2012). Strategic promotions can also backfire; Ohl \& Finkel (2014) find coups plotted by higher-ranking officers are more likely to succeed than those plotted by lower-ranking officers, soldiers, and civilians. Coupproofing measures, whether repressive or conciliatory, could inadvertently increase coup activity. Just as Machiavelli claims in The Prince, coup-wary leaders are torn between ruling through "fear," which reduces plotter capacity while also decreasing satisfaction with the leader, or ruling through "love," which increases satisfaction with the government but empowers capable factions that could remove the leader from power should they become more favorably disposed toward coup. This trade-off between plotter disposition and capacity constitutes the "civil-military problematique" described by Feaver (1999) and is the subject of many formal models of coup behavior (Acemoglu \& Robinson 2006, Gallego \& Pitchik 2004, Goldstone \& Tilly 2001).

The ultimate implication of this conceptual framework is that coup risk is codetermined by plotter disposition and capacity; the importance of each factor is conditioned by the other. Among potential plotters with very little capacity to overthrow the government, poor standing 
in the status quo is unlikely to result in coup activity. These dissatisfied potential plotters are dissuaded from coup attempts by their low chances of success, even when poor welfare under the incumbent leaves them favorably disposed to regime change. This implication is congruent with the finding that attempts from lower-ranking soldiers and civilians are infrequent and tend to be much more desperate and prone to failure than those initiated by higher-ranking military elites with greater plotter capacity (Ohl \& Finkel 2014). However, changes to plotter disposition become more consequential among those who have greater capacity to execute a successful coup. More capable plotters demand appeasement so that they do not become favorably disposed toward coup. Incumbents must be mindful of this relationship between disposition and capacity because coup risk is greatest where plotters are both sufficiently capable and disposed toward coup attempt.

\section{Ongoing Civil War and Coup Activity}

How might the presence of ongoing civil war alter this coup calculus? We argue that war is most likely to affect coup behavior by increasing plotter disposition for coup attempts. The hardships caused by war include both the immediate hazards of fighting and the long-term uncertainty caused by ongoing war with an outcome that is yet-to-be determined. By decreasing satisfaction in the status quo, war can lower the opportunity cost of coup activity and make capable plotters more favorably disposed toward risking an overt coup attempt. We also explore the implications of three alternate mechanisms that could plausibly link ongoing civil war to changes in coup activity. First, war may increase plotter capacity if the government's war effort undermines its ability to insulate itself from coup threats. Second, war may decrease plotter capacity if fighting rebels enables governments to more aggressively purge or eliminate potential coup plotters. And finally, war may decrease plotter disposition for coup attempts if the destruction and instability resulting from ongoing warfare diminish the rewards to be gained from taking over the government. Below, we show that these arguments produce divergent expectations about how war affects the frequency 
and outcomes of war-time coup attempts.

Ongoing civil war may make potential plotters less satisfied with the status quo and more favorably disposed toward coup activity for two reasons. First, civil war presents immediate, severe costs to both combatants and non-combatants. In addition to the hazards of warfare, members of the military may also face prolonged deployment, inadequate arms and equipment, or inconsistent pay. Because coup plots are most likely to emerge among members of the military, these combat-related risks and grievances are likely to greatly reduce plotter satisfaction with the incumbent government. These problems are especially acute in the under-developed states that face the highest risk of civil warfare and have the least resources to sustain their militaries. In Sierra Leone, for example, the war effort against the Revolutionary United Front was thwarted when dissatisfied and uncompensated members of the military turned against the state and attempted coups in April 1992, December 1992, October 1995, January 1996, and May 1997. In this case, the government's inability to pay its soldiers led to widespread dissatisfaction among the lower ranks. The first of these coups brought to power Valentine Strasser, a 25-year-old junior officer who became the world's youngest head-of-state.

War can also affect plotter disposition by increasing uncertainty about the future of the state. During war, the outcome of the war is uncertain and a potential plotter's satisfaction with the incumbent government is relevant only to the extent that the plotter believes the incumbent will prevail in the war. If there is any possibility that rebels could emerge victorious, demand concessions, and possibly replace the incumbent government, then potential coup plotters must anticipate their welfare should the rebels win. Any possibility of rebel victory must decrease satisfaction with the status quo for anyone who would not expect to benefit from rebel victory. ${ }^{6}$ The risk of concessions to rebels thus decreases the opportunity costs for coup plotting; as the status quo becomes

\footnotetext{
${ }^{6}$ Of course, some potential plotters could estimate that they would be unaffected or even better off should the rebels defeat the government. We argue that the overwhelming majority of viable coup plotters - and especially those made capable by high rank, political office, or access to the incumbent-would prefer the continuation of the incumbent's regime to a violent overthrow that could potentially result in political and/or military reorganization.
} 
less desirable, plotters become more favorably disposed toward coup. In these ways, ongoing war can reduce satisfaction among a large and capable set of potential coup plotters. The highly-ranked officers and elites who face lower or more indirect combat risks must worry about their post-war fates should the rebels achieve victory or concessions. Lower-ranked soldiers and civilians are more likely to suffer immediate combat-related costs that increase coup motivations. Successful coups rarely end wars, but state control offers successful plotters an opportunity to insulate themselves and their supporters from the worst of the conflict while also allowing them to negotiate their own post-war fates should rebels emerge victorious.

Following the logic outlined above, increased plotter disposition for coup should increase the frequency of coup attempts but decrease the likelihood with which coup attempts will succeed. The argument predicts these effects because plotters who are more favorably disposed to coup will initiate attempts when the chances of success are lower relative to plotters who are more content in the status quo. Very satisfied potential plotters do not have sufficient motivation to initiate a coup, and this makes them averse to initiating an attempt unless they are exceptionally likely to succeed. But as potential plotters become less satisfied and become more favorably disposed to coup, they become more willing to tolerate greater risks of failure and will attempt coup at a relatively lower threshold of plotter capacity. The adverse effect of ongoing civil war on plotter welfare makes riskier coup attempts more attractive, causing more coup attempts, though war-time coup attempts should have a lower success rate than those attempted when the state is not engaged in civil war.

This argument also suggests a strong link between coup activity and the degree to which rebels threaten the incumbent government, with respect to both rebel military capability and geographic proximity to the state capital. If potential plotters believe the ongoing war poses minimal risk to the incumbent, then there exists a smaller threat of future adverse political change. Though wars against less threatening rebels may cause some temporary grievances, they are unlikely to result in regime overthrow or reorganization. In the Russian war against Chechnya, for example, the vast distance between the conflict zone and Moscow and the relative weakness of Chechen forces 
relative to the Russian military meant Russian regime insiders had very little reason to fear that the war would end in the toppling of the government. We would expect these hypothesized effects of war on coup to be muted in this context. In contrast, the military strength of the Khmer Rouge and its proximity to the Cambodian capital of Phnom Penh fueled the widespread (and substantiated) fear that the rebels could forcibly seize control of the government. Here, where rebels were made more threatening by their fighting capacity and their proximity to the seat of government, the pernicious effects of ongoing war on coup activity should be much more pronounced. Given the contrasting levels of rebel threat, we would expect military elites in Cambodia to be much more favorably disposed toward coup — and even fairly risky coups — than their counterparts in Russia. We therefore derive the following testable hypotheses from this argument:

H1 (Frequency): Ongoing civil war increases the probability of coup attempts.

H2 (Outcome): Ongoing civil war decreases the probability with which attempted coups succeed. H3 (Rebel Threat): War-time coups are more likely when rebels have greater military capacity. H4 (Rebel Threat): War-time coups are more likely when a war zone is closer to the state capital.

\section{Alternate Mechanisms and Their Implications}

Next, we discuss three plausible alternate mechanisms that may link ongoing war to coup activity. We show the implications of these alternate arguments differ from those hypothesized above and then leverage these differences in our analysis to differentiate between these competing mechanisms. First, some researchers warn ongoing conflict may increase coup activity by increasing plotter capacity. Facing the threat of rebellion, political leaders are compelled to invest in their militaries. Civil war drives leaders to boost military spending, increase the role of the military in society, elevate military elites to more prominent public positions, and grant the military rights and privileges (instituting martial law, for example), that it is not afforded during peace-time (Acemoglu, Ticchi \& Vindigni 2010a). Yet, empowering the military increases the viability of 
coup attempts should the beneficiaries of these efforts decide to turn against the state (Acemoglu, Ticchi \& Vindigni 2010a, Acemoglu, Ticchi \& Vindigni 2010b, Svolik 2012). Also, war may require leaders to leave themselves more vulnerable by deploying loyal troops to the conflict zone. With a smaller, less capable, or less loyal military presence in the vicinity of the incumbent, dissident coup plotters could more easily overwhelm an incumbent's defenses and come to power. War can also increase the viability of coup attempts by reducing public support for the incumbent, especially where the government's war effort is perceived to be unsuccessful. Waning support for the incumbent legitimizes coups and decreases the likelihood that protests will overturn tactically successful coup attempts after the fact.

If ongoing war undermines incumbents vis-á-vis potential coup plotters, then ongoing war should increase the likelihood of coup attempts. Attempts should be more frequent because plotters with greater capacity face a lower risk of coup failure and a greater likelihood of successfully taking control of the state. The improved probability of success encourages attempts from plotters who might otherwise consider themselves to be too weak were the incumbent not hindered by ongoing civil war. Incumbents should be most weakened by wars against more threatening rebels, so the magnitude of this effect should increase with rebel threat. These implications are identical to those derived from an argument based on changing plotter disposition during war (see H1, H3, and H4 above). If war affects coup behavior by increasing plotter capacity, then we would also expect wartime coups to be more likely to be successful, all else being equal, than coups attempted during peace-time when incumbents are less vulnerable. This is an important deviation from Hypothesis 2. If war drives coup behavior by changing plotter disposition, then plotters attempt riskier coups but incumbents are no less likely to overcome these attempts. The result is a lower success rate due to more attempts against relatively secure governments. But if war drives coup behavior by increasing plotter capacity, then this should encourage more attempts and should also increase the share of coup attempts that are successful.

War could decrease plotter capacity if the pretense of war allows incumbent governments 
to better coup-proof their regimes. This second alternate mechanism emerges in the literature on how governments balance threats of coup and rebellion. Roessler (2011) links civil war to coupproofing by arguing that it is the strategic marginalization of potential coup plotters that provides the impetus for many civil wars. Others claim that war, in turn, can facilitate dictatorial consolidation (Migdal 1988, Huntington 1968) by allowing leaders to send threatening rivals to the war fronts while providing leaders with an invaluable opportunity to realign the military around loyalists. Belkin and Schofer (2005) apply this logic to interstate conflict, arguing that some leaders see war as an opportunity to weaken the military and coup-proof the regime by sending potential coup plotters to the war zone. War can also let leaders justify the creation of elite loyal paramilitaries that remain behind in the capital city. For example, the exponential expansion of the Hussein-controlled Iraqi Republican Guard relative to other branches of the Iraqi military during the Iran-Iraq war (1980-88) exemplifies this strategy. Further, redeployment during armed conflicts can weaken the bonds between the officers who pose the greatest coup threats and the troops they command and leaders may be able to undermine the legitimacy of the military or popular support for military elites by assigning blame after rebel gains. Powell (2012) suggests this may perpetuate a cycle of internal instability; while war might assist coup-proofing efforts, elite marginalization through coup-proofing can then increase the risk of subsequent civil war and insurgency.

This argument produces implications that are very different from those proposed above. If war insulates incumbents by decreasing plotter capacity, then war should decrease the frequency of coups and the magnitude of this effect should increase with rebel threat. Coup risk should decline as military elites are undermined by deployment and/or reorganization. More threatening wars provide a greater pretense for this kind of coup-proofing, so wars against more formidable and proximate rebels should decrease the rate of coup more dramatically than minor conflicts against weak rebels in the hinterlands. This suggests that Hypotheses 1, 3, and 4 should be reversed. The greater the threat of war, the lower the risk of coup. However, this argument would also predict the rate of coup success to be lower during war because incumbents can use war to make themselves 
less vulnerable than they would be during peace-time. This argument and one based on increased plotter disposition toward coup come to concurrent expectations about how ongoing war affects the likelihood of coup success (H2).

Finally, civil war is destructive and coming to power in a war-torn state may be less desirable than coming to power in a more stable state. During war, a successful coup would immediately place the new leader in the difficult position of deciding to either continue a war or make concessions to rebels. Continued violence may raise the risk of destabilizing political protests and counter-coups and this uncertainty about how long a potential plotter could remain in power should reduce the plotter's motivation to take power. Some leaders, including Sudan's Omar alBashir, have risen to power during war and held office for decades. But many others, including Osman (1966) and al-Dahab (1985)—both also in Sudan—executed war-time coups only to have their aspirations quickly undone by continued political violence. For this reason, we must also consider how war might affect coup behavior if the primary causal link between ongoing war and coup is a decrease in potential plotters' disposition toward coup activity.

Potential plotters who become less favorably disposed to coup activity should be less likely to initiate coup attempts. This occurs because war decreases the returns on a successful coup and makes the status quo more attractive relative to a coup attempt. The negative effect should become stronger when rebels pose a greater threat and therefore more significantly diminish the benefits to be gained from ousting the incumbent. These implications do not differentiate this mechanism from one derived from an argument about decreased plotter capacity, though the two mechanisms produce different expectations about how war affects coup success rates. If ongoing war makes coup less attractive, then we would expect potential coup plotters to be less tolerant of the risks inherent in staging a coup. Greater risk aversion would cause coup plotters to initiate attempts only if they perceive their chances of success to be exceptionally great. Perceived decreases in the payoffs of a successful coup decrease incentives for a coup attempt, and plotters should become less likely to plot coups that have a fair chance of failing. 
We can compare the viability of these alternate mechanisms because they suggest divergent predictions about (1) the effect of war on coup attempts, (2) the effect of war on the likelihood of coup success, and (3) the effect of the rebel threat on the frequency of coup attempts during war. These predictions are summarized in Table 1.

Table 1: Hypotheses Linking Ongoing Civil War to Coup Behavior

ARGUMENT

\begin{tabular}{lcccc} 
& $\begin{array}{c}\text { Disposition for } \\
\text { Coup Increases }\end{array}$ & $\begin{array}{c}\text { Capacity for } \\
\text { Coup Increases }\end{array}$ & $\begin{array}{c}\text { Capacity for } \\
\text { Coup Decreases }\end{array}$ & $\begin{array}{c}\text { Disposition for } \\
\text { Coup Decreases }\end{array}$ \\
\hline \hline H1: War makes coup... & More Frequent & More Frequent & Less Frequent & Less Frequent \\
H2: War makes coup... & Less Successful & More Successful & Less Successful & More Successful \\
H3/H4: Coup when rebels... & More Threatening & More Threatening & Less Threatening & Less Threatening
\end{tabular}

\section{Data and Descriptive Statistics}

We test our hypotheses with time-series cross-sectional data at the country-year unit-of-analysis. Our sample consists of the 193 states identified by the Correlates of War Project (2011) over the years 1950-2011. We use the entire sample to evaluate the effects of ongoing civil war on coup attempts (Hypothesis 1) and coup success (Hypothesis 2). To analyze the specific determinants of war-time coup attempts (Hypotheses 3 and 4), we use a sub-sample that includes only countryyear observations in which civil war was ongoing. This sub-sample includes observations from 93 states and approximates $15 \%$ of the greater sample. Our dependent variables, Coup Attempt and Successful Coup, are dichotomous variables derived from Powell \& Thyne (2011). Coups d'état are defined as overt attempts by the military or, very rarely, civilian elites to unseat the sitting headof-state using unconstitutional means. An attempt is coded as successful if the coup perpetrators seize and hold power for at least seven days (Powell \& Thyne 2011, 252). We estimate our models 
using Heckman probit models $(\mathrm{H} 1 / \mathrm{H} 2)$ and logit regressions $(\mathrm{H} 3 / \mathrm{H} 4)$ with robust standard errors clustered by country to address potential heteroskedasticity of observations within a given country.

We identify ongoing civil war with a dichotomous variable, Civil War, drawn from the UCDP/PRIO Armed Conflict Dataset v.4-2012 (Gleditsch et al. 2002, Themnér \& Wallensteen 2012). A qualifying armed conflict must include a government and a non-state groups, concern government and/or territory, and produce violence resulting in at least 25 battle-related deaths (UCDP \& PRIO 2013, 1). This dataset does not distinguish conflict between the government and rebel groups (i.e. civil war event) from violent conflict between the incumbent leader and regime elites (i.e. coup event). An obvious consequence of treating all these conflict cases in the UCDP/PRIO dataset as civil war events is that we could count the same events as both civil war and coup incidents, and thus would overestimate the impact of civil war on the incidence of coup activity (Hultquist 2013, Powell \& Thyne 2011). Fortunately, Powell \& Thyne (2011) identify the events within the Uppsala/PRIO dataset that are best described as coup attempts, thus allowing us to recode 37 "wars."7 Other potentially problematic cases occur when a country experiences both coup activity and the onset of civil war in the same year, but the coup incident precedes the beginning of the war. We need to avoid the pitfall of treating these cases as if civil war leads to the onset of coups in the same year in our analyses and consequently overestimating the impact of civil war on coup incidents. To do so, we excluded from our list of civil wars those country-year cases where both the onset of civil war and the coup occur but the coup event occurs before the civil war onset. Only six country-year observations in our data set meet this criterion and are recoded as peace-time coups: Yemen AR 1962, Ghana 1981, Afghanistan 1978, Guinea-Bissau 1998, Central Africa Republic 2001, and Ivory Coast 2002.

\footnotetext{
${ }^{7}$ The UCDP/PRIO conflict cases that are coded exclusively as coup events and are not considered as civil war in our analysis are Bolivia 1952, Paraguay 1954 and 1989, Guatemala 1954. Thailand 1951, Argentina 1963 , Iraq 1958 and 1959 and 1963, Ethiopia 1960, Venezuela 1962, Gabon 1964, Burundi 1965, Zaire 1965, Ghana 1966, Nigeria 1966, Syria 1966, Sudan 1971 and 1976, Morocco 1971, Uganda 1971, El Salvador 1972, Chile 1973, Somalia 1978, Equatorial Guinea 1979, Liberia 1980, Gambia 1981, Kenya 1982, Cameroon 1984, Togo 1991, Yemen PR 1986, Burkina Faso 1987, Comoros 1989, Panama 1989, Haiti 1989 and 1991, and Azerbaijan 1995.
} 
Table 2: Descriptive Statistics: Civil War and Coups

\begin{tabular}{lcc}
\hline & During Peace Time & During Civil War \\
\hline \hline Coup Attempt & 297 & 92 \\
& $(4.00 \%)$ & $(7.24 \%)$ \\
No Attempt & 7,137 & 1,178 \\
& $(96.00 \%)$ & $(92.76 \%)$ \\
Total & 7,434 & 1,270 \\
\hline \hline Successful Coup & 166 & \\
& $(55.89 \%)$ & $(46.74 \%)$ \\
Failed Coup & 131 & 49 \\
& $(44.11 \%)$ & $(53.26 \%)$ \\
Total & 297 & 92 \\
\hline \hline
\end{tabular}

Comparisons of Civil War against Coup Attempt and Successful Coup produce frequencies consistent with Hypotheses 1 and 2. Table 2 shows that of the 7,434 peace-time observations, $4.00 \%$ experienced coup attempts while $7.24 \%$ of 1,270 war-time observations experienced coup attempts. Strikingly, the success rate of the 92 war-time coup attempts (46.74\%) is nearly ten percentage points lower than the success rate of the 297 peace-time attempts $(55.89 \%)$.

We test Hypothesis 3 with two variables that capture the military strength of rebel groups relative to that of the government. The data on rebel capabilities are coded at the rebel groupyear unit-of-analysis, so we transform the data for our country-year study by using the fighting capabilities of the strongest rebel group active in each country-year. Rebel Fighting Capacity captures a rebel group's ability to "effectively engage the army militarily and win major battles, posing a credible challenge to the government" (Cunningham, Gleditsch \& Salehyan 2009). This variable is measured on a 1-3 scale, with 1 indicating the Fighting Capacity is much weaker than the government's fighting capacity, 2 meaning that the rebel's capacity is equal to the government's capacity, and 3 meaning that the rebel group's capacity is much stronger. Rebel Relative Strength, also from Cunningham, Gleditsch \& Salehyan (2009), is a more comprehensive measure of the rebel military strength and reflects a rebel group's organizational and mobilization capacity. It is 
measured on a 1-5 scale, with 1 meaning that the rebel group's organizational capacity is very weak, 3 meaning that the rebels are as strong as the government they fight, and 5 indicating that rebels are much stronger than the government. We hypothesize (H3) Rebel Fighting Capacity and Rebel Relative Strength increase the probability of a war-time coup attempt.

Hypothesis 4 links the extent of rebel threat to the physical distance between rebel forces and the seat of government power. Specifically, civil wars located closer to and especially inside the state capital pose a greater threat to the regime elites and military and, thus, more dramatically reduce their satisfaction with the status quo. We test this claim with Capital-War Distance, which is the logged distance in kilometers between the capital city and an ongoing civil conflict zone, and Capital War, a dichotomous variable coded as 1 if the conflict zone encompasses the state capital. We obtained the information for these variables from Buhaug, Gates \& Lujala (2009). When we observe multiple ongoing civil conflicts in the same country-year, we utilize the distance between the nearest conflict zone and the capital. Our argument expects Capital-War Distance to have a negative impact on war-time coup attempts (greater threat when coup is more proximate), while Capital War should increase coup risk. ${ }^{8}$

Table 3: Frequency of War-Time Coups

\begin{tabular}{lccccc}
\hline & & Rebel Fighting Capabilities & \multicolumn{2}{c}{ War Location } \\
& Weak & Equal & Strong & Outside Capital & Inside Capital \\
\hline \hline \multirow{2}{*}{ Coup Attempt } & 44 & 37 & 6 & & 5 \\
& $(6.41 \%)$ & $(12.98 \%)$ & $(20.69 \%)$ & $(8.18 \%)$ & $(19.23 \%)$ \\
No Coup Attempt & 642 & 248 & 23 & 921 & 21 \\
& $(93.59 \%)$ & $(87.02 \%)$ & $(79.31 \%)$ & $(91.82 \%)$ & $(80.77 \%)$ \\
\hline \multirow{2}{*}{ Total } & 686 & 285 & 29 & 1,003 & 26 \\
\hline
\end{tabular}

In Table 3, we provide some descriptive statistics showing the frequency of Coup Attempt

\footnotetext{
${ }^{8}$ For most conflicts, there is little temporal variation in the location of the conflict zone. The largest annual changes in this variable occur when new conflicts occur in locations more proximate to the capital. See Buhaug, Gates \& Lujala (2009) for further details.
} 
across the ranges of Rebel Fighting Capability and Capital War. First, of those observations where rebels are weaker than the government, $6.41 \%$ experienced coup attempts, while $12.98 \%$ of the observations with comparably strong rebels and $20.69 \%$ of observations with much stronger rebels experienced coup attempts. The location of the war also predicts coup activity: the frequency of coup is much higher when wars are fought in the state capital $(19.23 \%)$ rather than only beyond it $(8.18 \%)$. Both results are consistent with our prediction that coup activity is positively correlated with the threat rebels pose to incumbent governments. The alternate measures of these conceptsRebel Relative Strength and Capital-War Distance-have similar bivariate relationships with Coup Attempt (See the Appendix for table). The frequency of war-time coup is roughly five times higher when the conflict is located in the capital $(19.23 \%)$ rather than above the 75 th percentile (approximately $500 \mathrm{~km}$ ) of Capital-War Distance (3.91\%). War-time coup occurs in more than $7 \%$ of war-years in which rebels are "weak" or "very weak," but in more than $20 \%$ of those in which rebels are "strong" or "very strong."

We control for several other factors thought to affect coup attempts and outcomes. To capture plotter capacity, we include the natural log of military personnel (Log(Military Personnel $))$ and the natural log of military expenditures per soldier (Expenditure/Soldier). These variables account for the idea that soldiers can be appeased by military expansion and/or generous expenditures and will therefore be less likely (though better equipped) to execute a coup attempt. We obtain the information for these variables from the Correlates of War index on national capabilities (CINC, Version 3.02) (Singer 1987). Paramilitary and Counterbalancing assess coup-proofing strategies and are expected to reduce the military's capacity to organize a successful coup attempt. Paramilitary organizations have different—and often more direct—command structures relative to the regular armed forces and are considered to be valuable defenses against coups emerging from military elites (Quinlivan 1999). Following Powell (2012), we include Paramilitary as the ratio of paramilitary personnel to regular armed personnel. Counterbalancing, created by Belkin \& Schofer (2005), captures the government's efforts to divide the military and pit rival armed organizations against 
one another. Counterbalancing involves "the creation of additional military branches to prevent any one part of the military from controlling too many resources, for example, creating several distinct armies" (Belkin \& Schofer 2005, 613). Counterbalancing incorporates both the number of military organizations and the relative size of the paramilitary groups compared to the size of the regular army, based on the Military Balance published by the International Institute for Strategic Studies (IISS). We expect coups to be less likely at greater values of Paramilitary and Counterbalancing. ${ }^{9}$

We include $\log (G D P /$ capita) because recent economic performance influences public satisfaction with the incumbent and, consequently, the public's willingness to accept coup attempts (Galetovic \& Sanhueza 2000, Londregan \& Poole 1990). Data for these economic indicators come from Gleditsch (2002) and the Penn World Tables (Heston, Summers \& Aten 2012). Log(War Duration) measures how many years have passed since the beginning of a civil conflict. We include Log(War Duration) because it might influence potential coup plotters' evaluation of the status quo under the incumbent government. Military officers, for example, might become less satisfied with the incumbent leader when they face a prolonged war. In addition, following the literature, we control for regime type. Democracy and Military Dictatorship are dichotomous variables. Democracies are defined as regimes in which governmental offices are filled as a consequence of contested elections. Military dictatorships are those regimes in which the regime's decision makings rely on the armed forces within juntas. A base category in our analyses is a non-military dictatorship. Data on these variables come from Cheibub, Gandhi \& Vreeland (2010). To account for the duration dependency, we include Years after Coup which measures how many years have passed since the previous coup attempt, Years after Coup ${ }^{2}$ and Years after Coup ${ }^{3}$ (Carter \& Signorino 2010).

\footnotetext{
${ }^{9}$ We should note that here we are describing the literature's theoretical claims regarding the determinants of coup attempts and successful coups. These claims are not necessarily empirically supported in the previous studies. For example, Powell (2012) shows that his hypothesis about the positive impact of military size on coup success is not supported by his data. In the following section, we will overview our empirical results regarding these control variables and briefly compare them to the previous studies' findings.
} 


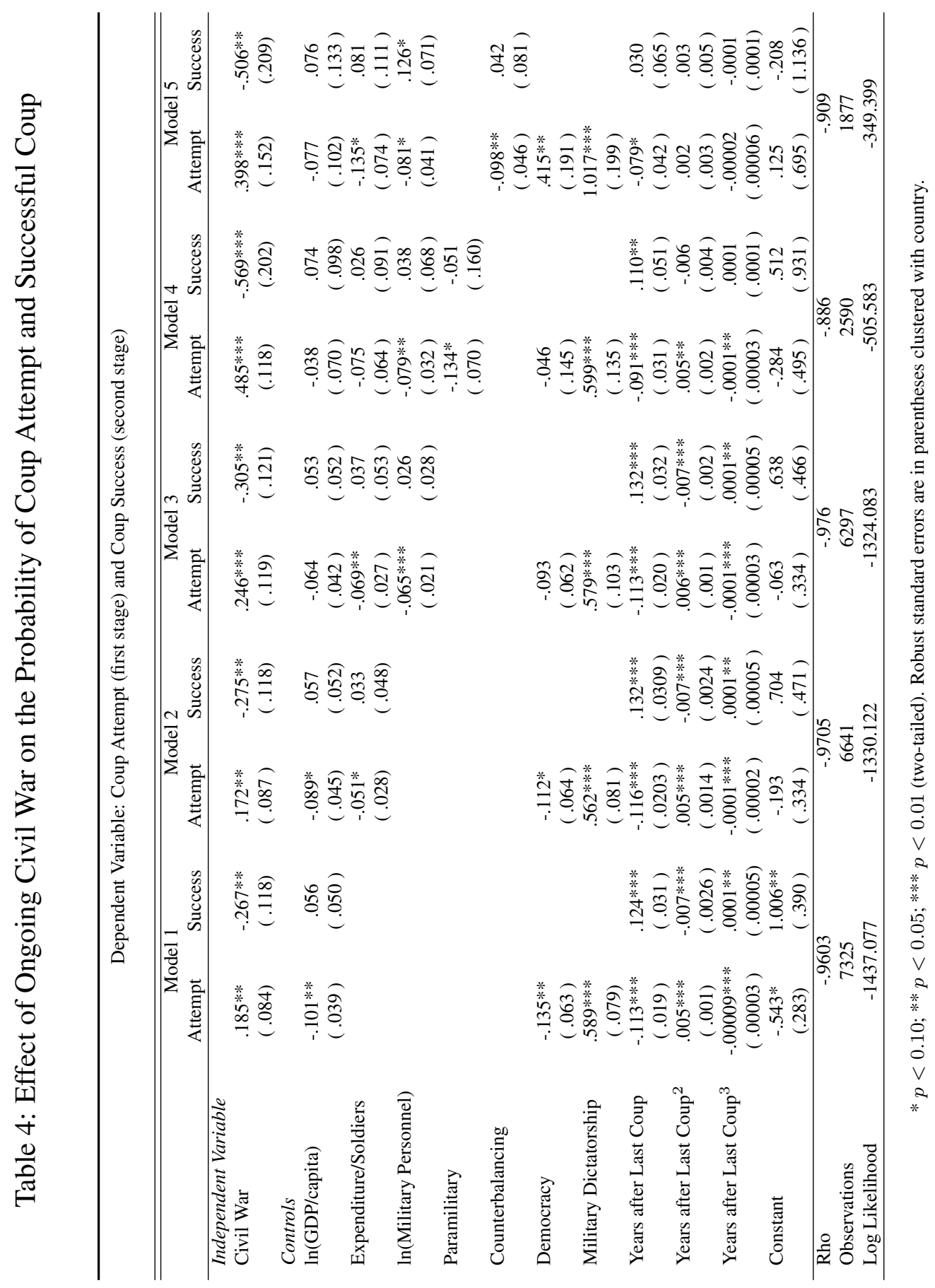




\section{Results}

Hypotheses 1 and 2 predict ongoing civil war increases the probability that countries suffer coup attempts but decreases the probability with which an attempted coup succeeds. Of course, coup success can occur only where coups are attempted, so we model this selection effect by using several Heckman probit models. This strategy allows us to differentiate between the causes of Coup Attempt (H1) in the selection stage and the causes of Successful Coup (H2) in the outcome stage. The results are provided in Table $4 .{ }^{10}$

Civil War significantly increases the probability that a country will experience a coup attempt within a given year. This can be seen by the positive and statistically significant coefficient on Civil War in the first stage equations of all five models shown in Table 4. Also, the coefficient on Civil War of the second stage of all five models is negative and significant, indicating that an ongoing civil war decreases the likelihood of successful coup given that a coup is attempted (H2). To evaluate the substantive effect of Civil War, we calculate the predicted probabilities of coup attempts and coup success during ongoing civil war (i.e. when a country-year experiences a civil war) and during peace (i.e. when there is no civil war in that year), and report them in the first and second column in Table 5. We also generate the first differences when we change the status of Civil War from 0 to 1 using the results from Model 3 in Table 4 and they are provided in the third and fourth columns in Table 5. Consistent with Hypothesis 1, the probability of a coup attempt is higher during ongoing civil war (.027) than it is when states are at peace (.015). When Civil War increases from 0 to 1 holding other variables constant at their means or medians, the first difference is .012 and statistically significant at the $p<0.01$ level. More precisely, the probability of coup attempt will increase by $81.93 \%$ when we increase Civil War from 0 to 1 . This indeed tells us that Civil War has a substantively strong positive effect on the probability of coup attempt.

\footnotetext{
${ }^{10}$ Note that, for identification purposes, we need to have at least one independent variable that appears in the selection equation but does not appear in the outcome equation. We ran various models to confirm that Democracy and Military Dictatorship do not have statistically significant impacts on the probability of successful coup given that a coup is attempted. We therefore drop Democracy and Military Dictatorship from the outcome equation in all models.
} 
Table 5: Effect of Ongoing Civil War on the Probability of Coup Attempt and Successful Coup

\begin{tabular}{lcccc}
\hline & \multicolumn{2}{c}{ Predicted Probability } & \multicolumn{2}{c}{ First Difference } \\
& During Peace Time & During Ongoing Civil War & Change in Probability & $\%$ Change \\
\hline \multirow{3}{*}{ Coup Attempts } & .015 & .027 & $.012^{* * * *}$ & $81.93 \%$ \\
& $(.003)$ & $(.006)$ & $(.005)$ & \\
Success Coups & .492 & .255 & $-.237^{* * *}$ & $-48.03 \%$ \\
& $(.002)$ & $(.002)$ & $(.001)$ & \\
\hline
\end{tabular}

Note: We present predicted probabilities and first differences using the result from Model 3 in Table 4 holding other variables constant at their means or medians. The first two columns provide the predicted probabilities of coup attempts and successful coups. In the third and fourth columns, we show the change in predicted probabilities and their percentage changes when Civil War changes from 0 to 1 . Standard errors are shown in parentheses. Statistically significant changes in predicted probability are indicated: $* p<0.10 ; * *$ $p<0.05$; *** $p<0.01$ (two-tailed). All estimates are based on simulations using 10,000 draws from the estimated coefficient vector and variance-covariance matrix.

We also present the substantive effect of Civil War on coup success in the second row in Table 5. We calculate the conditional (on selection) predicted probability of success $\operatorname{Pr}($ Success Coup $=1$, Coup Attempt $=1) / \operatorname{Pr}($ Coup Attempt $=1)$ during both peace-time and during civil war and report them in the first and second columns in Table 5. As expected by Hypothesis 2, the conditional predicted probability of successful coup is lower during a civil war (.255) than during a peace time (.492). An attempted coup is 23.7 percentage points less likely to be successful during war and this effect is statistically significant at the $p<0.01$ level. In other words, Civil War decreases the probability that an attempted coup will succeed by $48.03 \%$.

Taken together, these findings suggest our theoretical argument linking civil war to coups via increased disposition toward coups is more viable than alternative mechanisms. Specifically, as described in Table 1, our theoretical argument linking war to coup via increased disposition is the only one to predict that war has a positive effect on coup attempts but has a negative effect on coup success. On the other hand, alternative mechanisms are not consistent with the empirical results because they predict either a reductive effect of war on coup attempts or a positive effect of war on coup success.

The findings relating to the control variables reported in Table 4 are generally consistent with those reported in previous studies. The probability of a coup attempt decreases as military 
expenditure per soldier (Expenditure/Soldier) or the size of military (Military Personnel) increase. The included coup-proofing measures, Paramilitary (Model 4) and Counterbalancing (Model 5), significantly decrease the likelihood of a coup attempt. Military dictatorships are far more likely to suffer coup than civilian dictatorships, though the significance of democracy and economic performance is very sensitive to model specification.

Next, we examine whether war-time coup attempts are more likely to occur when rebel groups pose a more imminent threat to the regime in terms of their fighting capabilities and the location of war zone. To test these propositions, we include in our data only those country-years experiencing civil war. Using the sample of those war-time country-year observations from 1950 to 2011, we estimate eight logit models in Table 6. All eight models include our key independent variables that capture the rebel capabilities relative to the government and the proximity of the war zone to the capital. To evaluate the impact of rebel strength on war-time coup attempts (Hypothesis 3), we include Rebel Fighting Capability in Models 1-4 and Rebel Relative Strength in Models 5-8. To evaluate the effects of the proximity of the civil war zone to the state capital (Hypothesis 4), we use Capital-War Distance in Models 1, 2, 5 and 6 and Capital War in Models 3, 4, 7 and 8.

The results in Table 6 show that an increase in a rebel group's fighting capabilities and/or organization capacity increases the probability of war-time coup attempts. This can be seen in the positive and significant coefficients on Rebel Fighting Capability or Rebel Relative Strength in all eight models. To further evaluate our hypotheses, we report the predicted probabilities of war-time coup attempts across the ranges of Rebel Fighting Capacity and Rebel Relative Strength in the first and second column in Table $7 .{ }^{11}$ The reported "change in probability" in Table 7 is equivalent to the first difference generated by moving from one category of rebel strength/capacity to the other while holding all other variables constant at their means or medians.

\footnotetext{
${ }^{11}$ Note that Rebel Fighting Capability is measured on a 1-3 scale and Rebel Relative Strength is measured on a 1-5 scale. Accordingly we call the status of rebel strength/capability weaker when Rebel Fighting Capability and Rebel Relative Strength take a value of 1, equal when Rebel Fighting Capability is equal to 2 and Rebel Relative Strength is equal to 3, and stronger when Rebel Fighting Capability takes a value of 3, while Rebel Relative Strength takes a value of 5 .
} 
Table 6: Effects of Civil War Types on War-time Coup Attempts

\begin{tabular}{|c|c|c|c|c|c|c|c|c|}
\hline \multicolumn{9}{|c|}{ Dependent Variable: Coup Attempt } \\
\hline & Model 1 & Model 2 & Model 3 & Model 4 & Model 5 & Model 6 & Model 7 & Model 8 \\
\hline \multicolumn{9}{|l|}{ Independent Variables } \\
\hline $\ln$ (Capital-War Distance ) & $\begin{array}{c}-.144 * * * \\
(.053)\end{array}$ & $\begin{array}{c}-.144 * * * \\
(.054)\end{array}$ & & & $\begin{array}{c}-.139 * * \\
(.060)\end{array}$ & $\begin{array}{l}-.139 * * \\
(.061)\end{array}$ & & \\
\hline Capital War & & & $\begin{array}{l}.787 * * \\
(.356)\end{array}$ & $\begin{array}{l}.891^{* *} \\
(.354)\end{array}$ & & & $\begin{array}{l}.858 * * \\
(.395)\end{array}$ & $\begin{array}{l}.949 * * \\
(.387)\end{array}$ \\
\hline Rebel Fighting Capability & $\begin{array}{c}.514 * * * \\
(.178)\end{array}$ & $\begin{array}{l}.560 * * * \\
(.179)\end{array}$ & $\begin{array}{c}.494 * * * \\
(.181)\end{array}$ & $\begin{array}{l}.539 * * * \\
(.181)\end{array}$ & & & & \\
\hline Rebel Relative Strength & & & & & $\begin{array}{l}.272^{*} \\
(.152)\end{array}$ & $\begin{array}{c}.288^{*} \\
(.159)\end{array}$ & $\begin{array}{c}.276^{*} \\
(.151)\end{array}$ & $\begin{array}{c}.288^{*} \\
(.156)\end{array}$ \\
\hline \multicolumn{9}{|l|}{ Control Variables } \\
\hline $\ln$ (GDP/capita) & $\begin{array}{l}.285^{*} \\
(.155)\end{array}$ & $\begin{array}{l}.271^{*} \\
(.159)\end{array}$ & $\begin{array}{l}.296 * * \\
(.147)\end{array}$ & $\begin{array}{c}.277 * \\
(.154)\end{array}$ & $\begin{array}{l}.245 \\
(.168)\end{array}$ & $\begin{array}{l}.230 \\
(.174)\end{array}$ & $\begin{array}{l}.255 \\
(.156)\end{array}$ & $\begin{array}{l}.232 \\
(.163)\end{array}$ \\
\hline $\ln$ (Military Personnel) & $\begin{array}{l}-.035 \\
(.115)\end{array}$ & $\begin{array}{c}-.036 \\
(.119)\end{array}$ & $\begin{array}{c}-.072 \\
(.111)\end{array}$ & $\begin{array}{c}-.071 \\
(.116)\end{array}$ & $\begin{array}{l}-.062 \\
(.125)\end{array}$ & $\begin{array}{c}-.066 \\
(.128)\end{array}$ & $\begin{array}{c}-.090 \\
(.120)\end{array}$ & $\begin{array}{c}-.094 \\
(.124)\end{array}$ \\
\hline Expenditure/Soldiers & $\begin{array}{l}-.212^{*} \\
(.110)\end{array}$ & $\begin{array}{l}-.209^{*} \\
(.113)\end{array}$ & $\begin{array}{c}-.225 * * \\
(.113)\end{array}$ & $\begin{array}{l}-.225^{*} \\
(.117)\end{array}$ & $\begin{array}{l}-.206^{*} \\
(.111)\end{array}$ & $\begin{array}{l}-.204 * \\
(.114)\end{array}$ & $\begin{array}{l}-.222 * \\
(.114)\end{array}$ & $\begin{array}{l}-.221^{*} \\
(.116)\end{array}$ \\
\hline $\ln$ (War Duration) & & $\begin{array}{l}.186 \\
(.203)\end{array}$ & & $\begin{array}{l}.224 \\
(.209)\end{array}$ & & $\begin{array}{l}.141 \\
(.199)\end{array}$ & & $\begin{array}{l}.183 \\
(.205)\end{array}$ \\
\hline Democracy & $\begin{array}{l}.073 \\
(.447)\end{array}$ & $\begin{array}{c}.019 \\
(.434)\end{array}$ & $\begin{array}{l}.113 \\
(.448)\end{array}$ & $\begin{array}{c}.060 \\
(.437)\end{array}$ & $\begin{array}{c}.026 \\
(.455)\end{array}$ & $\begin{array}{c}-.023 \\
(.435)\end{array}$ & $\begin{array}{l}.075 \\
(.452)\end{array}$ & $\begin{array}{l}.023 \\
(.437)\end{array}$ \\
\hline Military Dictatorship & $\begin{array}{c}1.213 * * * \\
(.365)\end{array}$ & $\begin{array}{c}1.234 * * * \\
(.372)\end{array}$ & $\begin{array}{c}1.233 * * * \\
(.374)\end{array}$ & $\begin{array}{c}1.265^{* * * *} \\
(.383)\end{array}$ & $\begin{array}{c}1.196^{* * * *} \\
(.362)\end{array}$ & $\begin{array}{c}1.207 * * * \\
(.366)\end{array}$ & $\begin{array}{c}1.227 * * * \\
(.370)\end{array}$ & $\begin{array}{c}1.244 * * * \\
(.375)\end{array}$ \\
\hline Years after Last Coup & $\begin{array}{c}-.177 * * \\
(.081)\end{array}$ & $\begin{array}{c}-.176^{* *} \\
(.080)\end{array}$ & $\begin{array}{c}-.174 * * \\
(.079)\end{array}$ & $\begin{array}{c}-.175 * * \\
(.078)\end{array}$ & $\begin{array}{c}-.193 * * \\
(.076)\end{array}$ & $\begin{array}{l}-.193 * * \\
(.076)\end{array}$ & $\begin{array}{c}-.191 * * \\
(.075)\end{array}$ & $\begin{array}{c}-.192 * * * \\
(.074)\end{array}$ \\
\hline Years after Last Coup ${ }^{2}$ & $\begin{array}{l}.011^{*} \\
(.006)\end{array}$ & $\begin{array}{l}.011^{*} \\
(.006)\end{array}$ & $\begin{array}{l}.011^{*} \\
(.005)\end{array}$ & $\begin{array}{l}.011^{*} \\
(.005)\end{array}$ & $\begin{array}{l}.013 * * \\
(.005)\end{array}$ & $\begin{array}{l}.013^{* *} \\
(.006)\end{array}$ & $\begin{array}{l}.012 * * \\
(.005)\end{array}$ & $\begin{array}{l}.012 * * \\
(.006)\end{array}$ \\
\hline Years after Last Coup ${ }^{3}$ & $\begin{array}{l}-.0002^{*} \\
(.0001)\end{array}$ & $\begin{array}{l}-.0002^{*} \\
(.0001)\end{array}$ & $\begin{array}{l}-.0002 * \\
(.0001)\end{array}$ & $\begin{array}{l}-.0002^{*} \\
(.0001)\end{array}$ & $\begin{array}{c}-.0002 * * \\
(.0001)\end{array}$ & $\begin{array}{l}-.0002^{*} \\
(.0001)\end{array}$ & $\begin{array}{c}-.0002^{*} \\
(.0001)\end{array}$ & $\begin{array}{l}-.0002 * \\
(.0001)\end{array}$ \\
\hline Constant & $\begin{array}{l}-2.416^{*} \\
(1.442) \\
\end{array}$ & $\begin{array}{l}-2.360 \\
(1.513) \\
\end{array}$ & $\begin{array}{c}-3.047 * * \\
(1.349) \\
\end{array}$ & $\begin{array}{c}-3.339 * * \\
(1.405) \\
\end{array}$ & $\begin{array}{c}-1.868 \\
(1.547) \\
\end{array}$ & $\begin{array}{c}-2.01 \\
(1.588) \\
\end{array}$ & $\begin{array}{c}-2.513^{*} \\
(1.376) \\
\end{array}$ & $\begin{array}{l}-2.649 * \\
(1.407) \\
\end{array}$ \\
\hline Observations & 924 & 924 & 924 & 924 & 924 & 924 & 924 & 924 \\
\hline Log Likelihood & -228.8681 & -228.337 & -229.475 & -228.712 & -230.0392 & -229.719 & -230.347 & -229.816 \\
\hline
\end{tabular}

${ }^{*} p<0.05 ; * *<0.01$ (two-tailed). Robust standard errors are in parentheses clustered with country. 
Table 7: Effect of Rebel Capabilities and War Location on the Probability of War-Time Coup Attempt

\begin{tabular}{|c|c|c|c|c|}
\hline \multirow{2}{*}{$\begin{array}{l}\text { Variables } \\
\mathbf{A} \longrightarrow \mathbf{B}\end{array}$} & \multicolumn{2}{|c|}{ Predicted Probability } & \multirow[t]{2}{*}{ Change in Probability } & \multirow[t]{2}{*}{ Percentage Change } \\
\hline & $\mathbf{A}$ & B & & \\
\hline \multicolumn{5}{|l|}{ Fighting Capability } \\
\hline Weaker $\longrightarrow$ Stronger & $\begin{array}{l}.037 \\
(.014)\end{array}$ & $\begin{array}{l}.098 \\
(.038)\end{array}$ & $\begin{array}{c}.061 * * * \\
(.031)\end{array}$ & $162.8 \%$ \\
\hline Weaker $\longrightarrow$ Equal & $\begin{array}{l}.037 \\
(.014)\end{array}$ & $\begin{array}{c}.060 \\
(.021)\end{array}$ & $\begin{array}{c}.023^{* * * *} \\
(.010)\end{array}$ & $61.6 \%$ \\
\hline Equal $\longrightarrow$ Stronger & $\begin{array}{l}.060 \\
(.021)\end{array}$ & $\begin{array}{l}.098 \\
(.038)\end{array}$ & $\begin{array}{c}.038^{* * * *} \\
(.021)\end{array}$ & $62.6 \%$ \\
\hline \multicolumn{5}{|l|}{ Rebel Strength } \\
\hline Weaker $\longrightarrow$ Stronger & $\begin{array}{l}.037 \\
(.016)\end{array}$ & $\begin{array}{l}.103 \\
(.050)\end{array}$ & $\begin{array}{l}.066^{*} \\
(.049)\end{array}$ & $185.5 \%$ \\
\hline Weaker $\longrightarrow$ Equal & $\begin{array}{l}.037 \\
(.016)\end{array}$ & $\begin{array}{l}.060 \\
(.022)\end{array}$ & $\begin{array}{l}.023^{*} \\
(.015)\end{array}$ & $65.1 \%$ \\
\hline Equal $\longrightarrow$ Stronger & $\begin{array}{c}.060 \\
(.022)\end{array}$ & $\begin{array}{c}.103 \\
(.050)\end{array}$ & $\begin{array}{l}.043^{*} \\
(.034)\end{array}$ & $72.9 \%$ \\
\hline \multicolumn{5}{|l|}{ Capital War } \\
\hline Outside Capital $\longrightarrow$ Inside Capital & $\begin{array}{c}.036 \\
(.014)\end{array}$ & $\begin{array}{c}.077 \\
(.032)\end{array}$ & $\begin{array}{l}.041^{* *} \\
(.025)\end{array}$ & $113.3 \%$ \\
\hline \multicolumn{5}{|l|}{ Capital-War Distance } \\
\hline Mean $\longrightarrow$ Mean +1 SD & $\begin{array}{c}.038 \\
(.014)\end{array}$ & $\begin{array}{l}.030 \\
(.012)\end{array}$ & $\begin{array}{c}-.008 * * * \\
(.004)\end{array}$ & $-19.8 \%$ \\
\hline 10th $\longrightarrow 90$ th percentile & $\begin{array}{c}.044 \\
(.017) \\
\end{array}$ & $\begin{array}{c}.030 \\
(.012) \\
\end{array}$ & $\begin{array}{c}-.014 * * * \\
(.008)\end{array}$ & $-32.2 \%$ \\
\hline \multicolumn{5}{|c|}{$\begin{array}{l}\text { Note: We present both predicted probabilities of war-time coup attempts and first differences using the results from Models } \\
1,3 \text { and } 5 \text { in Table } 6 \text {, holding other variables constant at their means or medians. We report the predicted probability of } \\
\text { war-time coup attempts when the status of Fighting Capability, Rebel Strength, Capital War and Capital-War Distance is A } \\
\text { in the first column and when it is B in the second column. The third column indicates the change in predicted probabilities } \\
\text { of war-time coup attempts when we change their status from A to B. The fourth column also shows their percentage change. } \\
\text { Standard errors are shown in parentheses. Statistically significant changes in predicted probability are indicated: } * p<0.10 \text {; } \\
* * p<0.05 \text {; *** } p<0.01 \text { (two-tailed). }\end{array}$} \\
\hline
\end{tabular}

The results in Table 7 demonstrate that the probability of war-time coup attempt is .037 when Rebel Fighting Capacity is weak, .060 when it is moderate, and .098 when it is high. Moreover, the change in the predicted probability of war-time coup when the rebel group's strength increases is statistically significant. For example, when we change the status of Rebel Fighting Capability from 1 (a weaker rebel) to 3 (a stronger rebel), the predicted probability of war-time coup attempt increases by .061 and it is statistically significant at $p<0.01$. In fact, this is equivalent to a $162.8 \%$ increase in the probability of war-time coup attempt. We obtain similar results regarding 
Rebel Relative Strength. Overall, the results in Tables 6 and 7 provide very strong evidence in support of Hypothesis 3. War-time coup attempts are more likely to occur when the government faces a stronger rebel group.

Finally we turn to Hypothesis 4, which claims war-time coup attempts are more likely when the civil war is fought closer to the state capital. As expected, the closer a civil war zone to the capital, the greater the likelihood of a war-time coup attempt. There is a negative and significant coefficient on Capital-War Distance in all four models in which it is included in Table 6. The results in Table 6 also demonstrate that a war-time coup attempt is more likely to occur when a war zone encompasses the capital city, which can be seen by the positive and statistically significant coefficient on Capital War of all four models in which it is included. To evaluate the substantive impact of the proximity of the civil war zone to the capital on war-time coup attempts, we also present both the predicted probabilities of war-time coup attempts and the first differences of the predicted probabilities when we change Capital-War Distance or Capital War in Table 7. First, the results indicate that the predicted probability of war-time coup attempts will decrease by .008 (from .038 to .030) when we increase Capital-War Distance by one standard deviation from its mean and it is significant at $p<0.01$. A one standard deviation increase in Capital-War Distance from its mean will reduce the predicted probability of war-time coup attempts by $19.8 \%$. When Capital-War Distance increases from the 10th to the 90th percentile, the predicted probability of war-time coup attempts decreases by .014 (from .044 to .030). This is equivalent to a $32.2 \%$ reduction in the probability of war-time coup attempt and is statistically significant at $p<0.01$. We can also confirm that a change in Capital War also leads to a substantively important change in the predicted probability of war-time coup attempts. When we increase Capital War from 0 (not present) to 1 (present), the predicted probability of a war-time coup attempt increases .041 (from .036 to .077$)$ and is statistically significant at $p<0.05$. War-time coup attempts are $113 \%$ more likely to happen when a civil war zone encompasses the capital city. 


\section{Conclusion}

Nearly one in four of the coups attempted since 1950 occurred in the context of an ongoing civil war. These fateful and important war-time coups include seizures of power by Omar al-Bashir (Sudan, 1989), Lon Nol (Cambodia, 1970), Efrain Rios Montt (Guatemala, 1982), and Mobutu Sese Seku (Congo-Kinshasa, 1965)_leadership transitions that precipitated some of the greatest humanitarian disasters in recent history. Above, we argue that the increased risk of coup during civil war is neither coincidental nor spurious. Ongoing civil war can change a coup plotter's calculus by dramatically altering plotter satisfaction with the status quo.

By focusing on the effect of ongoing civil war on plotters' dispositions, we deduce that (1) coup attempts should be more likely during ongoing civil wars, yet (2) coup attempts should be less likely to be successful during ongoing civil wars and (3) war-time coup attempts should be more likely when rebel groups are perceived to pose a more imminent threat to the incumbent government. An empirical analysis of nearly 200 states (1950-2011) shows that an ongoing civil war has a positive impact on the probability of coup attempts but has a negative impact on the probability of successful coup given an attempted coup. Moreover, we find war-time coup attempts are more likely to occur when rebel groups have greater fighting capacity and/or fight closer to the state's capital city.

Importantly, these findings do not suggest coups and civil wars are similarly driven by other factors that increase a state's vulnerability to extra-constitutional threats. Were this the case, then we would expect coups attempted against extraordinarily vulnerable war-suffering states to be more-and certainly not less-likely to succeed than those attempted against less vulnerable states experiencing peace. Our tests result in significant effects in the opposite direction, and this suggests to us that war affects coup decisions by altering plotter disposition rather than plotter capacity.

Leaders of unconsolidated and conflict-prone states face several concurrent threats to their power, so it is imperative for researchers to consider the interactions of these vulnerabilities. To 
this point, the literatures on civil war, coup, mass protests, non-violent movements, and other types of extra-constitutional mechanisms for leader replacement have developed mostly independently (Blattman \& Miguel 2010, Sambanis 2004). By considering the interactions of these threats and the implications for both leaders and dissidents, we might gain a superior understanding of political survival, repression, and regime consolidation. Several pertinent questions remain under-explored, such as how leaders must manage coup-proofing and rebellion-proofing efforts (Roessler 2011), how coups alter the course of civil wars (Thyne 2015), and how coup timing relates to cease-fires and peace agreements. By focusing on such questions, conflict research might shed light on how leaders can best maintain peace and stability in the face of multiple threats . This synthesis will be important if we are to gain a more comprehensive understanding of political instability and political violence. 


\section{References}

Acemoglu, Daron, Davide Ticchi \& Andrea Vindigni. 2010a. "Persistence of Civil Wars." Journal of the European Economic Association 8(2-3):664-676.

Acemoglu, Daron, Davide Ticchi \& Andrea Vindigni. 2010b. "A Theory of Military Dictatorships." American Economic Journal : Macroeconomics 2:1-42.

Acemoglu, Daron \& James A. Robinson. 2006. Economic Origins of Dictatorship and Democacy. New York: Cambridge University Press.

Arriola, Leonardo R. 2009. "Patronage and Political Stability in Africa." Comparative Political Studies 42(10):1339-1362.

Belkin, Aaron \& Evan Schofer. 2003. "Toward a Structural Understanding of Coup Risk." Journal of Conflict Resolution 47(5):594-620.

Belkin, Aaron \& Evan Schofer. 2005. "Coup Risk, Counterbalancing, and International Conflict." Security Studies 14(1):140-177.

Bell, Curtis. 2011. "Buying Support and Buying Time: The Effect of Regime Consolidation on Public Goods Provision.” International Studies Quarterly 55(3):625-646.

Blattman, Christopher \& Edward Miguel. 2010. "Civil War.” Journal of Economic Literature 48(1):3-57.

Bueno de Mesquita, Bruce, Alastair Smith, Randolph M. Siverson \& James D. Morrow. 2003. The Logic of Political Survival. Cambridge, MA: MIT Press.

Buhaug, Halvard, Scott Gates \& Paivi Lujala. 2009. "Geography, Rebel Capability, and the Duration of Civil Conflict." Journal of Conflict Resolution 53(4):544-569.

Carter, David \& Curtis S. Signorino. 2010. "Back to the Future; Modeling Time Dependence in Binary Data." Political Analysis 18(3):271-292.

Cheibub, Jose Antonio, Jennifer Gandhi \& James Raymond Vreeland. 2010. "Democracy and Dictatorship Revisited.” Public Choice 143:67-101.

Chiozza, Giacomo \& H. E. Goemans. 2011. Leaders and International Conflict. New York: Cambridge University Press.

Correlates of War Project. 2011. "State System Membership List, v2011." www.correlatesofwar.org .

Cunningham, David E., Kristian Skrede Gleditsch \& Idean Salehyan. 2009. "It Takes Two: A Dyadic Analysis of Civil War Duration and Outcome." Journal of Conflict Resolution 53:570-597. 
Feaver, Peter D. 1999. “Civil-Military Relations.” Annual Review of Political Science 2:211-241.

Finer, Samuel J. 1988. The Man on Horseback: The Role of the Military in Politics. Boulder, CO: Westview.

Galetovic, Alexander \& Ricardo Sanhueza. 2000. "Citizens, Autocrats, and Plotters: A Model and New Evidence on Coups D’Ėtat.” Economics and Politics 12(2):183-204.

Gallego, M. \& C. Pitchik. 2004. "An Economic Theory of Leadership Turnover." Journal of Public Economics 88(12):2361-2382.

Gillespie, Charles Guy. 1991. Negotiating Democracy: Politicians and Generals in Uruguay. New York: Cambridge University Press.

Gleditsch, Nils Petter, Peter Wallensteen, Mikael Eriksson, Margareta Sollenberg \& Havard Strand. 2002. “Armed Conflict 1946-2001: A New Dataset." Journal of Peace Research 39:615-637.

Goldstone, Jack A. \& Charles Tilly. 2001. “Threat (and Opportunity): Popular Action and State Response in the Dynamics of Contentious Action". In Silence and Voice in the Study of Contentious Politics, ed. Ronald R. Aminzade, Jack A Goldstone, Doug McAdam, Elizabeth J. Perry, William H. Sewell Jr., Sidney Tarrow \& Charles Tilly. New York: Cambridge University Press pp. 179-194.

Heston, Alan, Robert Summers \& Bettina Aten. 2012. Penn World Table Version 7.1. Center for International Comparisons of Production, Income, and Prices at the University of Pennsylvania.

Hultquist, Philip. 2013. "Power Parity and Peace? The Role of Relative Power in Civil War Settlement." Journal of Peace Research 50(5):623-634.

Huntington, Samuel P. 1968. Political Order in Changing Societies. Cambridge, MA: Harvard University Press.

Kposowa, Augustine J. \& J. Craig Jenkins. 1993. "The Structural Sources of Military Coups in Postcolonial Africa, 1957-1984." American Journal of Sociology 99(1):126-163.

Lindberg, Staffan I. \& John F. Clark. 2008. "Does Democratization Reduce the Risk of Military Interventions in Politics in Africa." Democratization 15(1):86-105.

Londregan, John B. \& Keith T. Poole. 1990. "Poverty, the Coup Trap, and the Seizue of Executive Power." World Politics 42(2):151-183.

Luttwak, Edward. 1969. Coup d'État. London: Penguin.

Migdal, Joel S. 1988. Strong Societies and Weak States: State-Society Relations and State Capabilities in the Third World. Princeton University Press. 
Nordlinger, Eric A. 1977. Soldiers in Politics: Military Coups and Governments. Englewood Cliffs, NJ: Prentice Hall.

Ohl, Dorothy \& Evgeny Finkel. 2014. “Coups and Military Ranks.” Available Online.

Pion-Berlin, David \& Harold A. Trinkunas. 2007. "Attention Deficits: Why Politicians Ignore Defense Policy in Latin America." Latin American and Caribbean Studies 42(3):76-100.

Powell, Jonathan. 2012. "Determinants of the Attempting and Outcome of Coups d'État." Journal of Conflict Resolution 56(6):1017-1040.

Powell, Jonathan M. \& Clayton L. Thyne. 2011. "Global Instances of Coups from 1950 to 2010: A New Dataset." Journal of Peace Research 48(2):249-259.

Quinlivan, James T. 1999. "Coup-Proofing: Its Practice and Consequences in the Middle East." International Security 24(1):131-165.

Roessler, Philip. 2011. "The Enemy Within: Personal Rule, Coups, and Civil War in Africa." World Politics 63(2):300-346.

Sambanis, Nicholas. 2004. "What is Civil War? Conceptual and Empirical Complexities of an Operational Definition." Journal of Conflict Resolution 48(6):814-858.

Singer, J. David. 1987. "Reconstructing the Correlates of War Dataset on Material Capabilities of States, 1816-1985." International Internations 14:115-132.

Svolik, Milan W. 2009. "Power Sharing and Leadership Dynamics in Authoritarian Regimes." American Journal of Political Science 53(2):477-494.

Svolik, Milan W. 2012. "Contracting on Violence: The Moral Hazard in Authoritarian Repression and Military Intervention in Politics." Journal of Conflict Resolution 57(5):765-794.

Themnér, Lotta \& Peter Wallensteen. 2012. “Armed Conflict, 1946-2011.” Journal of Peace Research 49(4):565-575.

Thyne, Clayton L. 2010. "Supporter of Stability or Agent of Agitation? The Effect of US Foreign Policy on Coups in Latin America, 1960-99.” Journal of Peace Research 47(4):449-461.

Thyne, Clayton L. 2015. "The Impact of Coups d'État on Civil War Duration.” Conflict Management and Peace Science Forthcoming.

UCDP \& PRIO. 2013. “Armed Conflict Dataset Codebook Version 4-2013.”. Accessed 2013-0313.

URL: www.pcr.uu. se/research/ucdp/datasets

Wang, T.Y. 1998. “Arms Transfers and Coups d'État: A Study on sub-Saharan Africa.” Journal of Peace Research 35(6):659-675. 


\section{Online Appendix A: Additional Descriptive Statistics}

Table 8: Rebel Relative Strength and War-Time Coups

\begin{tabular}{lccccc}
\hline & & & Rebel Relative Strength & & \\
& Very Weak & Weak & Equal & Strong & Very Strong \\
\hline \hline Coup Attempt & 16 & 46 & 19 & 6 & 0 \\
& $(6.20 \%)$ & $(7.72 \%)$ & $(16.38 \%)$ & $(22.22 \%)$ & $(0.00 \%)$ \\
No Coup Attempt & 242 & & & 21 & 4 \\
& $(93.80 \%)$ & $(92.28 \%)$ & $(83.62 \%)$ & $(77.78 \%)$ & $(100.00 \%)$ \\
\hline Total & 258 & 596 & 116 & 27 & 4 \\
\hline \hline
\end{tabular}

Table 9: Capital-War Distance and War-Time Coups

\begin{tabular}{lcccc}
\hline & Inside Capital & $\begin{array}{c}\text { Capital-War Distance } \\
<75 \text { th percentile } \\
(<235 \mathrm{~km})\end{array}$ & $\begin{array}{c}\geq 75 \text { th percentile } \\
(\geq 533 \mathrm{~km})\end{array}$ \\
\hline \hline Coup Attempt & 5 & 42 & 25 & 20 \\
& $(19.23 \%)$ & $(8.90 \%)$ & $(9.58 \%)$ & $(3.91 \%)$ \\
No Coup Attempt & 21 & 430 & 236 & 491 \\
& $(80.77 \%)$ & $(91.10 \%)$ & $(90.42 \%)$ & $(96.09 \%)$ \\
\hline Total & 26 & 472 & 261 & 511 \\
\hline
\end{tabular}

